\title{
UJI VALIDITAS KONSTRUK PADA INSTRUMEN RELIGIUSITAS DENGAN METODE CONFIRMATORY FACTOR ANALYSIS (CFA)
}

\author{
Farah Hanifah Purnomo \\ Farahhanifa13@gmail.com \\ Guru BK Bintang Pelajar
}

\author{
Bambang Suryadi \\ Bangs1970@gmail.com \\ Fakultas Psikologi UIN Syarif \\ Hidayatullah Jakarta
}

\begin{abstract}
Huber and Huber's religiosity is the mind and belief that a person has to view the world that affects their experiences and behaviors in everyday life. Religiosity consists of five dimensions, namely intellectual, ideology, public practice, private practice, and religious experience. This study aims to examine the validity of the construct of religious instruments. Data in this study were obtained from 209 students at SMAN 87 and SMK Tunas Pembangunan. The method used is confirmatory factor analysis (CFA) with software $M$ Plus 7. The results of this study indicate that of the 33 items that exist, there are 2 items that are not valid. So there are 31 items that are unidimensional. The item measures only one factor.
\end{abstract}

Keyword :construct validity test, religiosity, confirmatory factor analysis (CFA).

\begin{abstract}
Abstrak
Religiusitas menurut Huber dan Huber adalah pikiran dan keyakinan yang dimiliki seseorang untuk memandang dunia sehingga mempengaruhi pengalaman dan perilaku mereka dalam kehidupan sehari- hari. Religiusitas terdiri dari lima dimensi, yaitu intellectual, ideology, public practice, private practice, dan religious experience. Penelitian ini bertujuan untuk menguji validitas konstruk instrumen religiusitas. Data dalam penelitian ini diperoleh dari 209 siswa pada SMAN 87 dan SMK Tunas Pembangunan. Metode yang digunakan adalah confirmatory factor analysis (CFA) dengan software M Plus 7. Hasil dari penelitian ini menunjukkan bahwa dari 33 item yang ada, terdapat 2 item yang tidak valid. Sehingga terdapat 31 item yang bersifat unidimensional. Artinya, item tersebut hanya mengukur satu faktor saja.
\end{abstract}

Katakunci : Uji validitas konstruk, religiusitas, confirmatory factor analysis (CFA). 


\section{PENDAHULUAN}

Religiusitas merupakan sesuatu yang kompleks dan konstruk yang multidimensional. Religiusitas berbeda dengan spiritualitas. Religiusitas berasal dari kata religion (agama). Arti religion dalam Kamus Lengkap Psikologi (Chaplin, 2006) berarti bagian dari kepercayaan, keyakinan, sikap-sikap dan upacaraupacara yang menghubungkan individu dengan Tuhan. Sedangkan religious dalam the New American Webster Dictionary (Morehead, 2001) memiliki sinonim dengan God-fearing, orthodox, sound, strict, canonical, authentic, faithful, theological, doctrinal, dogmatic, denominational, sectarian.

Huber (dalam Murken \& Namini, 2004) mendefinisikan religiusitas sebagai pikiran dan keyakinan yang dimiliki seseorang untuk memandang dunia sehingga mempengaruhi pengalaman dan perilaku mereka dalam kehidupan sehari-hari. Huber menyebut pikiran dan keyakinan yang dimiliki seseorang untuk memandang dunia sebagai personal construck system. Huber dan Huber (2012) berpendapat bahwa religiusitas seseorang dapat diukur dari intensitas menjalankan kewajiban dan nilai- nilai agama yang paling menonjol dalam diri seseorang. Huber dan Huber (2012), merevisi aspek religiusitas menjadi lima aspek berbeda, yaitu:

\section{Intellectual}

Adalah pengetahuan yang dimiliki seseorang mengenai agamanya, sehingga ia dapat menjelaskan pandangan mereka mengenai Tuhan, agama, dan keberagamaan.

2. Ideology

Adalah kepercayaan yang dimiliki seseorang yang berkaitan dengan keberadaan dan makna kehidupan serta hubungan antara Tuhan dan manusia.

3. Public practice (Ibadah publik)

Adalah ibadah yang dilakukan seseorang dan dimanifestasikan dalam partisipasinya dalam ritual, upacara dan aktivitas keagamaan.

4. Private practice (Ibadah pribadi)

Adalah ibadah yang dilakukan seseorang yang ditunjukkan dengan mencurahkan dirinya pada Tuhan dalam aktivitas, ibadah dan ritual yang dilakukan sendiri.

5. Religious experience (Pengalaman beragama)

Mengarah pada pengalaman kontak langsung seseorang dengan Tuhan, sehingga berdampak secara emosional pada diri mereka.

Untuk mengukur religiusitas peneliti melakukan modifikasi pada alat ukur oleh Stefan Huber dan Odilo W. Huber (2012) yaitu The Centrality of Religiosity Scale (CRS). Item dalam skala ini berbentuk favorable dan unfavorable. Item favorable adalah item yang memiliki nilai tertinggi pada pernyataan "Sangat Setuju" dan penilaian terendah pada pernyataan "Sangat Tidak Setuju". Sementara item unfavorable adalah item yang memiliki nilai tertinggi pada pernyataan "Sangat Tidak Setuju" dan penilaian terendah pada pernyataan "Sangat Setuju".

Alat ukur ini mengukur lima dimensi dasar, yaitu intellectual, ideology, public practice, private practice, dan religious experience. Alat ukur ini terdiri dari 33 item, 15 item adalah item yang telah diadaptasi dalam aspek bahasa, sementara peneliti menambahkan 18 item baru. Alasannya karena peneliti menambahkan beberapa 
bentuk dimensi menjadi lebih spesifik dan disesuaikan dengan pemahaman remaja. Seperti pada item asli "How often do you take part in religious services?" dibagi menjadi tiga item yang lebih spesifik mengukur religious services. Blueprint skala ini dapat dilihat dalam tabel berikut.

Tabel 1

Skala Religiusitas

\begin{tabular}{|c|c|c|c|c|}
\hline \multirow[t]{2}{*}{ Dimensi } & \multirow[t]{2}{*}{ Indikator } & \multicolumn{2}{|l|}{ Nomor Item } & \multirow[t]{2}{*}{$\mathrm{Jml}$} \\
\hline & & Fav & Unfav & \\
\hline Intellectual & $\begin{array}{l}\text { Memiliki pengetahuan } \\
\text { Tertarik dengan topik } \\
\text { agama }\end{array}$ & $\begin{array}{l}1,2,3, \\
4,5,6\end{array}$ & 7 & 7 \\
\hline Ideology & $\begin{array}{l}\text { Mempercayai Tuhan dan } \\
\text { ciptaan-Nya }\end{array}$ & $8,9,10$ & & 9 \\
\hline & Meyakini ajaran agama & $11,13,14,15,16$ & 12 & \\
\hline Public practice & $\begin{array}{l}\text { Beribadah berjamaah } \\
\text { Merasa beribadah } \\
\text { berjamaah penting }\end{array}$ & $\begin{array}{r}17,18,19 \\
20,21\end{array}$ & 28 & 6 \\
\hline Private practice & $\begin{array}{l}\text { Beribadah individual } \\
\text { Merasa beribadah } \\
\text { individual penting }\end{array}$ & $\begin{array}{r}22,23,24,25 \\
26,27\end{array}$ & & 6 \\
\hline Religious Experience & $\begin{array}{l}\text { Merasakan adanya kuasa } \\
\text { Tuhan } \\
\text { Memiliki pengalaman } \\
\text { keagamaan }\end{array}$ & $\begin{array}{r}29,30,31 \\
32,33\end{array}$ & & 5 \\
\hline Total & & 30 & 3 & 33 \\
\hline
\end{tabular}

\section{Alat ukur Religiusitas}

Alat ukur religiusitas terdiri dari 33 item, 15 item adalah item yang telah diadaptasi dalam aspek bahasa, 18 item baru. Alasannya karena penulis menambahkan beberapa bentuk dimensi menjadi lebih spesifik dan disesuaikan dengan pemahaman remaja. Untuk lebih jelas bisa melihat Tabel 2 terlampir.

\section{METODE PENELITIAN}

Uji validitas instrumen dengan menggunakan Confirmatory Factor Analysis (CFA). Uji. instrumen ini diberikan kepada seluruh sampel. Adapun prosedur uji validitas konstruk dengan CFA adalah sebagai berikut (Umar, 2012):

1. Dibuat atau disusun suatu definisi operasional tentang konsep yang hendak diukur. Untuk mengukur konsep tersebut diperlukan item (stimulus) sebagai indikatornya.

2. Disusun hipotesis/teori bahwa seluruh item yang disusun adalah valid mengukur konstruk yang didefinisikan. Dengan kata lain diteorikan (hipotesis) bahwa hanya ada 1 faktor yang diukur yaitu konstruk yang didefinisikan (model unidimensional).

3. Berdasarkan data yang diperoleh kemudian dihitung matriks korelasi antar item, yang disebut matriks $S$. 
4. Matriks korelasi tersebut digunakan untuk mengestimasi matriks korelasi yang seharusnya terjadi menurut teori atau model yang ditetapkan. Jika teori/hipotesis pada butir dua adalah benar, maka semestinya semua item hanya mengukur satu faktor saja (unidimensional).

5. Adapun langkah-langkanyaadalah:

- Dihitung parameter dari teori/model yang diuji yang dalam hal ini terdiri dari koefisien muatan faktor dan varian kesalahan pengukuran (residual).

- Setelah nilai parameter diperoleh kemudian dihitung korelasi antarsetiap item sehingga diperoleh matriks korelasi antar item berdasarkan hipotesis/teori yang diuji (matriks korelasi ini disebut sigma).

6. Uji validitas konstruk dilakukan dengan menguji hipotesis bahwa $\mathrm{S}=\sum$ atau dapat dituliskan $\mathrm{H}_{0}$ : $\mathrm{S}-\Sigma=0$. Uji hipotesis ini misalnya dilakukan menggunakan uji Chi-Square, dimana jika Chi-Square tidak signifikan $(\mathrm{p}>0,05)$ maka dapat disimpulkan bahwa hipotesis nihil $\left(\mathrm{H}_{0}\right)$ tidak ditolak. Artinya teori yang mengatakan bahwa semua item hanya mengukur satu konstruk saja terbukti sesuai (fit) dengan data.

7. Jika telah terbukti model unidimensional (satu faktor) fit dengan data maka dapat dilakukan seleksi terhadap item dengan menggunakan tiga kriteria, yaitu:

- Item yang koefisien muatan faktornya tidak signifikan dieliminasi karena tidak memberikan informasi yang secara statistik bermakna.

- Item yang memiliki koefisien muatan faktornya negatif juga dieliminasi karena mengukur hal yang berlawanan dengan konsep yang didefinisikan. Namun demikian, harus diperiksa dahulu apakah item yang pernyataannya unfavorable atau negatif sudah disesuaikan (direverse) skornya sehingga menjadi positif. Hal ini berlaku khusus untuk item dimana tidak ada jawaban yang benar atau salah (misalnya, alat ukur personality, motivasi, persepsi, dsb).

- Item juga dapat dieliminasi jika residualnya (kesalahan pengukuran) berkorelasi dengan banyak residual item yang lainnya, karena ini berarti bahwa item tersebut mengukur hal lain selain konstruk yang hendak diukur.

Jika langkah di atas telah dilakukan, maka diperoleh item yang valid untuk mengukur apa yang hendak diukur. Pada penelitian ini, tidak menggunakan raw score/skor mentah (hasil menjumlahkan skor item). Item-item inilah yang diolah untuk mendapatkan faktor skor pada setiap skala. Dengan demikian perbedaan kemampuan setiap item dalam mengukur apa yang hendak diukur ikut menentukan dalam menghitung faktor skor (true score). True score inilah yang dianalisis dalam penelitian ini.

Untuk kemudahan di dalam penafsiran hasil analisis faktor skor yang diukur ditransformasikan dalam skala baku ( $Z$ score) menjadi $T$ score yang memiliki mean $=50$ dan standar deviasi $(\mathrm{SD})=10$, sehingga tidak ada responden yang mendapat skor negatif. Adapun rumus $T$ score yaitu $T$ score $=(10 \mathrm{x}$ skor faktor $)+50$. Untuk menguji validitas alat ukur yang digunakan dalam penelitian ini, digunakan Confirmatory Factor Analysis(CFA) dengan software MPlus 7. 


\section{Intellectual}

\section{HASIL PENELITIAN}

Pada uji validitas intellectual, peneliti menguji apakah ketujuh item yang ada bersifat unidimensional artinya benar hanya mengukur intellectual saja, melalui uji CFA dengan menggunakan model first order. Hasil perhitungan awal dari variabel ini diperoleh nilai Chi-Square $=135,557, \mathrm{df}=14, P$-Value $=0,000$, dan RMSEA $=$ 0,204 . Dengan $P$-Value $0,000(<0,05)$ dan RMSEA $0,204(>0,05)$ yang artinya model ini belum fit. Maka peneliti melakukan modifikasi terhadap model ini, yaitu dengan membebaskan setiap item untuk berkorelasi. Setelah dilakukan empat kali modifikasi, diperoleh nilai Chi-Square $=18,108, \mathrm{df}=10, P$-Value $=$ $0,0532, \mathrm{RMSEA}=0,062$. Dengan $P$-Value 0,0532 artinya model ini sudah fit. Dengan demikian item pada variabel intellectual benar hanya mengukur satu faktor saja. Selanjutnya adalah melihat signifikan atau tidaknya item dalam mengukur apa yang hendak diukur, sekaligus menentukan apakah terdapat item yang perlu untuk dieliminasi atau tidak. Pengujiannya dilakukan dengan melihat T-Value bagi setiap koefisien muatan faktor, jika T-Value $>1,96$ artinya item tersebut signifikan dan begitu juga sebaliknya. Koefisien muatan faktor untuk item pengukuran intellectual disajikan dalam tabel di bawah ini.

\section{Tabel 3}

\section{Muatan Faktor Item Intellectual}

\begin{tabular}{llllll}
\hline No. Item & Estimate & S.E. & T- Value & $P$-Value & Signifikan \\
1 & 0.972 & 0.090 & 10.815 & 0.000 & $\sqrt{ }$ \\
2 & 0.803 & 0.083 & 9.670 & 0.000 & $\sqrt{ }$ \\
3 & 0.424 & 0.084 & 5.069 & 0.000 & $\sqrt{ }$ \\
4 & 0.441 & 0.075 & 5.857 & 0.000 & $\sqrt{ }$ \\
5 & 0.223 & 0.087 & 2.573 & 0.010 & $\sqrt{ }$ \\
6 & 0.303 & 0.083 & 3.634 & 0.000 & $\sqrt{ }$ \\
7 & 0.091 & 0.092 & 0.992 & 0.321 & $\mathrm{X}$ \\
\hline
\end{tabular}

Berdasarkan tabel di atas dapat diketahui bahwa terdapat enam item yang bermuatan positif dan signifikan, sementara satu item memiliki $T$-Value $<1,96$, sehingga satu item ini akan dieliminasi. Oleh karena itu terdapat enam item yang akan dianalisis lebih lanjut.

\section{Ideology}

Pada uji validitas ideology, peneliti menguji apakah sembilan item yang ada bersifat unidimensional artinya benar hanya mengukur ideology saja, melalui uji CFA dengan menggunakan model first order. Hasil perhitungan diperoleh nilai Chi-Square $=46,603, \mathrm{df}=27, P$ - Value $=0,0109$, dan $\mathrm{RMSEA}=0,05$. Dengan nilai RMSEA $0,05(<0,05)$ yang artinya model ini sudah fit. Dengan demikian item pada variabel ideology benar hanya mengukur satu faktor saja. Kemudian untuk melihat signifikan atau tidaknya item dalam mengukur apa yang hendak diukur, sekaligus menentukan apakah terdapat item yang perlu untuk dieliminasi atau tidak. Pengujiannya dilakukan dengan melihat T-Value bagi setiap koefisien muatan faktor, jika $T$-Value $>1,96$ artinya item tersebut signifikan dan begitu juga 
sebaliknya. Koefisien muatan faktor untuk item pengukuran ideology disajikan dalam tabel di bawah ini.

\section{Tabel 4}

\section{Muatan Faktor Item Ideology}

\begin{tabular}{llllll}
\hline No. Item & Estimate & S.E. & T-Value & P-Value & Signifikan \\
\hline 8 & 0.896 & 0.070 & 12.754 & 0.000 & $\sqrt{ }$ \\
9 & 0.821 & 0.072 & 11.333 & 0.000 & $\sqrt{ }$ \\
10 & 0.970 & 0.033 & 29.086 & 0.000 & $\sqrt{ }$ \\
11 & 0.673 & 0.096 & 7.035 & 0.000 & $\sqrt{ }$ \\
12 & 0.185 & 0.076 & 2.423 & 0.015 & $\sqrt{ }$ \\
13 & 0.887 & 0.041 & 21.871 & 0.000 & $\sqrt{ }$ \\
14 & 0.962 & 0.038 & 25.604 & 0.000 & $\sqrt{ }$ \\
15 & 0.986 & 0.026 & 38.668 & 0.000 & $\sqrt{ }$ \\
16 & 0.901 & 0.043 & 21.042 & 0.000 & $\sqrt{ }$ \\
\hline
\end{tabular}

Berdasarkan table di atas dapat diketahui bahwa seluruh item bermuatan positif dan signifikan, yaitu memiliki $T$-Value $<1,96$.

\section{Public Practice}

Pada uji validitas public practice, peneliti menguji apakah keenam item yang ada bersifat unidimensional artinya benar hanya mengukur public practice saja, melalui uji CFA dengan menggunakan model first order. Hasil perhitungan diperoleh nilai Chi-Square $=34,115, \mathrm{df}=9, \quad P$-Value $=0,0001$, dan RMSEA $=0,116$. Dengan $P$ Value $0,001(<0,05)$ dan RMSEA $0,116(>0,05)$ yang artinya model ini belum fit. Maka peneliti melakukan modifikasi terhadap model ini, yaitu dengan membebaskan setiap item untuk berkorelasi.Setelah dilakukan dua kali modifikasi, diperoleh nilai Chi-Square $=13,543, \mathrm{df}=7, P$-Value $=0,0599, \mathrm{RMSEA}=$ 0,067 . Dengan $P$-Value 0,0599 artinya model ini sudah fit. Dengan demikian item pada variabel public practice benar hanya mengukur satu faktor saja. Kemudian untuk melihat signifikan atau tidaknya item dalam mengukur apa yang hendak diukur, sekaligus menentukan apakah terdapat item yang perlu untuk dieliminasi atau tidak. Pengujiannya dilakukan dengan melihat T-Value bagi setiap koefisien muatan faktor, jika T-Value $>1,96$ artinya item tersebut signifikan dan begitu juga sebaliknya. Koefisien muatan faktor untuk item pengukuran public practice disajikan dalam table di bawah ini.

\section{Tabel 5}

Muatan Faktor Item Public Practice

\begin{tabular}{llllll}
\hline No. Item & Estimate & S.E. & T-Value & $P$-Value & Signifikan \\
\hline 17 & 0.499 & 0.074 & 6.775 & 0.000 & $\sqrt{ }$ \\
18 & 0.544 & 0.055 & 9.809 & 0.000 & $\sqrt{ }$ \\
19 & 0.814 & 0.049 & 16.67 & 0.000 & $\sqrt{ }$ \\
20 & 0.928 & 0.047 & 19.830 & 0.000 & $\sqrt{ }$ \\
21 & 0.717 & 0.046 & 15.472 & 0.000 & $\sqrt{ }$ \\
28 & -0.003 & 0.075 & -0.044 & 0.965 & $\mathrm{X}$ \\
\hline
\end{tabular}


Berdasarkan tabel di atas dapat diketahui bahwa lima item bermuatan positif dan signifikan, sedangkan satu item bermuatan negatif dan tidak signifikan serta memiliki $T$-Value $<1,96$, sehingga satu item ini akan dieliminasi.

\section{Private Practice}

Pada uji validitas private practice, peneliti menguji apakah keenam item yang ada bersifat unidimensional artinya benar hanya mengukur private practice saja, melalui uji CFA dengan menggunakan model first order. Hasil perhitungan awal diperoleh nilai Chi-Square $=53,483, \mathrm{df}=9, P$-Value $=0,0000$, dan $\mathrm{RMSEA}=0,154$. Dengan $P$-Value $0,000(<0,05)$ dan RMSEA $0,154(>0,05)$ yang artinya model ini belum fit. Maka peneliti melakukan modifikasi terhadap model ini, yaitu dengan membebaskan setiap item untuk berkorelasi.Setelah dilakukan dua kali modifikasi, diperoleh nilai Chi-Square $=13,891, \mathrm{df}=7, P$-Value $=0,0532, \mathrm{RMSEA}=$ 0,069 . Dengan $P$-Value 0,0532 artinya model ini sudah fit. Dengan demikian item pada variabel private practice benar hanya mengukur satu faktor saja. Kemudian untuk melihat signifikan atau tidaknya item dalam mengukur apa yang hendak diukur, sekaligus menentukan apakah terdapat item yang perlu untuk dieliminasi atau tidak. Pengujiannya dilakukan dengan melihat T-Value bagi setiap koefisien muatan faktor, jika T-Value $>1,96$ artinya item tersebut signifikan dan begitu juga sebaliknya. Koefisien muatan faktor untuk item pengukuran private practice disajikan dalam tabel di bawah ini.

\section{Tabel 6}

Muatan Faktor Item Private Practice

\begin{tabular}{llllll}
\hline No. Item & Estimate & S.E. & T-Value & P-Value & Signifikan \\
\hline 22 & 0.431 & 0.088 & 4.875 & 0.000 & $\sqrt{ }$ \\
23 & 0.890 & 0.093 & 9.516 & 0.000 & $\sqrt{ }$ \\
24 & 0.750 & 0.074 & 10.076 & 0.000 & $\sqrt{ }$ \\
25 & 0.656 & 0.066 & 9.921 & 0.000 & $\sqrt{ }$ \\
26 & 0.564 & 0.078 & 7.194 & 0.000 & $\sqrt{ }$ \\
27 & 0.783 & 0.116 & 6.750 & 0.000 & $\sqrt{ }$ \\
\hline
\end{tabular}

Berdasarkan tabel di atas dapat diketahui bahwa keenam item yang ada bermuatan positif dan signifikan serta memiliki T-Value $>1,96$. Oleh karena itu keenam item yang ada akan dianalisis lebih lanjut.

\section{Religious Experience}

Pada uji validitas religious experience, peneliti menguji apakah kelima item yang ada bersifat unidimensional artinya benar hanya mengukur religious experience saja, melalui uji CFA dengan menggunakan model first order. Hasil perhitungan awal diperoleh nilai Chi-Square $=19,964, \mathrm{df}=5, P$-Value $=0,0013$, dan RMSEA= 0,120 . Dengan $P$-Value $0,013(<0,05)$ dan RMSEA $0,120(>0,05)$ yang artinya model ini belum fit. Maka peneliti melakukan modifikasi terhadap model ini, yaitu dengan membebaskan setiap item untuk berkorelasi.Setelah dilakukan satu kali modifikasi, diperoleh nilai Chi-Square $=8,835, \mathrm{df}=4, P$-Value $=0,0653$, 
RMSEA $=0,076$. Dengan P-Value 0,0653 artinya model ini sudah fit. Dengan demikian item pada variabel religious experience benar hanya mengukur satu faktor saja. Kemudian untuk melihat signifikan atau tidaknya item dalam mengukur apa yang hendak diukur, sekaligus menentukan apakah terdapat item yang perlu untuk dieliminasi atau tidak. Pengujiannya dilakukan dengan melihat T-Value bagi setiap koefisien muatan faktor, jika T-Value $>1,96$ artinya item tersebut signifikan dan begitu juga sebaliknya. Koefisien muatan faktor untuk item pengukuran religious experience disajikan dalam tabel di bawah ini.

\section{Tabel 7}

Muatan Faktor Item Religious Experience

\begin{tabular}{llllll}
\hline No. Item & Estimate & S.E. & T-Value & P-Value & Signifikan \\
\hline 29 & 0.470 & 0.086 & 5.475 & 0.000 & $\sqrt{ }$ \\
30 & 0.787 & 0.045 & 17.603 & 0.000 & $\sqrt{ }$ \\
31 & 0.882 & 0.039 & 22.682 & 0.000 & $\sqrt{ }$ \\
32 & 0.814 & 0.040 & 20.395 & 0.000 & $\sqrt{ }$ \\
33 & 0.866 & 0.040 & 21.892 & 0.000 & $\sqrt{ }$ \\
\hline
\end{tabular}

Berdasarkan tabel di atas dapat diketahui bahwa kelima item yang ada bermuatan positif dan signifikan serta memiliki T-Value $>1,96$.

\section{KESIMPULAN}

Hasil uji validitas konstruk menggunakan pendekatan confirmatory factor analysis (CFA) mengungkapkan bahwa seluruh item bersifat unidimensional, dengan catatan terdapat dua item yang tidak valid yaitu item no 7 dan 28. Meski terdapat 2 item yang tidak valid, hal tersebut tetap bisa dikatakan valid dan bersifat unidimensional. Kriteria sebagai item yang baik, yaitu (1) memiliki muatan faktor positif, (2) valid (signifikan, $\mathrm{t}>1,96$ atau $\mathrm{t}<-1.96$ ).

\section{DAFTAR PUSTAKA}

Chaplin, J.P. 2001. Kamus lengkap psikologi, Terjemahan Kartini Kartono. Jakarta: PT Raja Grafindo Persada.

Huber, Stefan \& Odilo W. Huber. 2012. The centrality of religiosity scale. Religions, 3, 710-724.

Pye, Michael, Edith, Frank, Alef Theria Wasim \& Abdurrahman Ma'sud. 2004. Religious harmony. Berlin: Walter deGruyter.

Umar, J. 2012. Confirmatory factor analysis: Bahan ajar perkuliahan, Jakarta: UIN Syarif Hidayatullah. 
Lampiran

\section{Tabel 2}

\section{Alat Ukur Religiusitas}

\begin{tabular}{|c|c|c|c|c|}
\hline & No Pernyataan & STS & TS & $\mathrm{S}$ SS \\
\hline 1 & Saya mengetahui ajaran agama Saya & & & \\
\hline 2 & Saya memahami ajaran agama Saya & & & \\
\hline 3 & Saya memikirkan permasalahan/isu mengenai agama & & & \\
\hline 4 & Saya tertarik mempelajari lebih dalam topik agama & & & \\
\hline 5 & $\begin{array}{l}\text { Saya mengikuti informasi permasalahan agama melalui } \\
\text { radio, televisi, internet, koran, maupun buku }\end{array}$ & & & \\
\hline 6 & $\begin{array}{l}\text { Saya mencari tahu jawaban mengenai permasalahan } \\
\text { agama melalui radio, televisi, internet, koran atau buku }\end{array}$ & & & \\
\hline 7 & Saya kurang tertarik membicarakan masalah/isu agama & & & \\
\hline 8 & Saya percaya bahwa Tuhan itu ada & & & \\
\hline 9 & Saya percaya adanya kekuatan yang Maha Besar & & & \\
\hline 10 & Saya percaya bahwa makhluk adalah ciptaan Tuhan & & & \\
\hline 11 & $\begin{array}{l}\text { Saya percaya adanya kehidupan setelah kematian, } \\
\text { seperti hari kebangkitan ataupun reinkarnasi }\end{array}$ & & & \\
\hline 12 & Saya tidak yakin bahwa ajaran agama Saya adalah benar & & & \\
\hline 13 & Saya percaya bahwa adanya Utusan Tuhan & & & \\
\hline 14 & Saya percaya dengan kitab suci agama Saya & & & \\
\hline 15 & Saya yakin dengan kebenaran agama Saya & & & \\
\hline 16 & Saya yakin bahwa ajaran agama Saya adalah benar & & & \\
\hline 17 & $\begin{array}{l}\text { Saya melakukan ibadah di tempat ibadah, seperti masjid, } \\
\text { gereja, pura, vihara, dsb }\end{array}$ & & & \\
\hline 18 & Saya menghadiri acara-acara keagamaan & & & \\
\hline 19 & Saya mengikuti komunitas keagamaan & & & \\
\hline 20 & $\begin{array}{l}\text { Penting bagi Saya untuk mengikuti acara keagamaan di } \\
\text { tempat ibadah, seperti masjid, gereja, pura, vihara. }\end{array}$ & & & \\
\hline 21 & Penting bagi Saya untuk mengikuti komunitas keagamaan & & & \\
\hline 22 & Saya melakukan ibadah individual/dikerjakan sendirian & & & \\
\hline 23 & Saya berdo'a kepada Tuhan & & & \\
\hline 24 & $\begin{array}{l}\text { Saya berdo'a secara tiba-tiba ketika mengalami kejadian } \\
\text { yang membuat Saya tersentuh }\end{array}$ & & & \\
\hline 25 & Saya mencoba untuk dekat dengan Tuhan & & & \\
\hline 26 & $\begin{array}{l}\text { Peting bagi Saya untuk melakukan ibadah yang bersifat } \\
\text { individual atau yang dikerjakan sendirian }\end{array}$ & & & \\
\hline 27 & Penting bagi Saya untuk berdo'a kepada Tuhan & & & \\
\hline 28 & $\begin{array}{l}\text { Saya merasa sia-sia untuk mengikuti acara keagamaan di } \\
\text { tempat ibadah, seperti masjid, gereja, pura, vihara. }\end{array}$ & & & \\
\hline 29 & Saya merasa ada campur tangan Tuhan dalam kehidupan & & & \\
\hline 30 & $\begin{array}{l}\text { Saya mengalami keadaan dimana Tuhan sepert } \\
\text { menunjukkan jalan atau mengungkap sesuatu pada Saya }\end{array}$ & & & \\
\hline 31 & $\begin{array}{l}\text { Saya mengalami keadaan yang membuat Saya merasa } \\
\text { Tuhan itu nyata }\end{array}$ & & & \\
\hline 32 & $\begin{array}{l}\text { Saya mengalami keadaan yang membuat Saya merasa } \\
\text { menyatu dengan segalanya }\end{array}$ & & & \\
\hline 33 & $\begin{array}{l}\text { Saya mengalami keadaan dimana Saya merasa tersentuh } \\
\text { karena kuasa Tuhan }\end{array}$ & & & \\
\hline
\end{tabular}


Uji validitas konstruk pada instrumen religiusitas dengan metode confirmatory factor analysis (CFA) 